\title{
Research Regarding the Impact Behaviour of Some Polymeric Bio-composite Products for Orthopedic Use
}

\author{
CONSTANTIN OPRAN ${ }^{2 *}$, DIANA COTOROS², NADINNE ROMAN², ANGELA REPANOVICI ${ }^{2}$, ROXANA MICLAUS ${ }^{2}$ \\ ${ }^{1}$ Politechnic University of Bucharest, 313 Splaiul Independentei, 060042, Bucharest, Romania \\ ${ }^{2}$ Transilvania University of Brasov, 29 Eroilor Av., 500036, Brasov, Romania
}

\begin{abstract}
Polymeric bio-composites have special characteristics and use in various areas such as: automotive, aviation and aeronautic industries, civil engineering and for medical devices manufacturing. This paper presents the evaluation of impact behaviour of some types of materials suitable for orthopaedic use. As composites behave very differently at different rates of loading, static strength tests cannot be used to predict impact behaviour in the perspective of prosthetic medical devices study and manufacture. The used testing machine is Instron Dynatup Impact System with Data Acquisition and Control, model 8200, with assisted system of data acquisition and control.
\end{abstract}

Keywords: polymeric bio-composite product, prosthesis manufacturing, impact test

Polymeric bio-composite materials are nowadays widely used in manufacturing processes, for daily objects or in automotive industry, in the high-tech sector, but also in the medical fields, related to medical devices bioengineering, our paper approaching especially the prosthesis manufacturing.

Bio-engineering means the application of concepts and methods of the physical science, mathematics in an engineering approach for solving problems in repair and reconstruction of lost, damaged or non-functional tissue [1]. Composite materials including natural sources (like wood for example) have significant development in the recent years in many fields and in the medical area, they offer weight reduction, add functionality and occupational health benefits, preserve the environment [2]. Wood fibre has a low density structure, is a low cost material and is a biodegradable element, attracting the scientists atention during the last decades [3] but it seems that the principal disadvantage of the wooden fiber reinforcement is represented by the structure's hydrophylic nature when compared with carbon or glass fibers [4].

Medical rehabilitation or physiatry is a medical field with multiple pathologies, from neurologic disorders with limb, hemibody or body impairment to orthopedic trauma sequelae, congenital disorders of the musculoskeletal system and other momement disfunctions [5]. In the medical rehabilitation field, the recovery of motor function is the major objective and with the active orthosis, simple orthosis or external prosthesis, the rehabilitation or physical therapy treatment objectives are much more achievable, butalso the proper device for rehabilitation is very important for recovery [6-8]. The prosthesis or orthosis design is very important in the rehabilitation process, because the disease manifestations differ from one to another patient. Besides it is necessary to correlate the technical problems with patients' needs and rights, with health care services and hospital facilities [9]. Nowadays the prosthesis and orthosis manufacturing is growing rapidly due to $3 \mathrm{D}$ printing processes and devices, computed aded design software but also due to bio-materials development[10]. These materials are well known for the extremely complex behaviour strongly depending on the time and the temperature.
They are also constantly subjected to dynamical shock stress due to daily activities or even accidental, [11] therefore the paper presents the evaluation of impact behaviour for two different types of polymeric biocomposites materials: polymeric bio-composites fibre reinforced wooden beech and polymeric bio-composites fibre reinforced wooden fir.

\section{Experimental part}

Impact test on polymeric materials is a test measuring the resistance to failure of a material to a suddenly applied force. The impact test measures the impact energy or the energy absorbed prior to fracture [12, 13]. It is most commonly used to evaluate the relative toughness or impact toughness of materials, often in quality control applications (critically important if medical devices are involved), as it is a fast, reliable and economical test.

The w orking principle is based on the fact that when the striker impacts the specimen, this absorbs the energy until it yields. When the specimen cannot absorb more energy, fracture occurs [14]. The testing machine that we used is an Instron Dynatup impact system with data acquisition and control, model 8200, (fig. 1).

The impact testing system has: maximum gravity mode velocity up to $5.0 \mathrm{~m} / \mathrm{s}$, maximum spring assisted high velocity up to $20 \mathrm{~m} / \mathrm{s}$, maximum physical drop height of 1.25 meters, self-id load cell for measuring drop mass. The 8200 type is ideal for low energy testing of thin section or brittle plastics, composites, ceramics, and metals [14].

Experiments were performed on materials made from polymeric bio-composites fibre reinforced wooden beech and polymeric bio-composites fibre reinforced wooden fir.

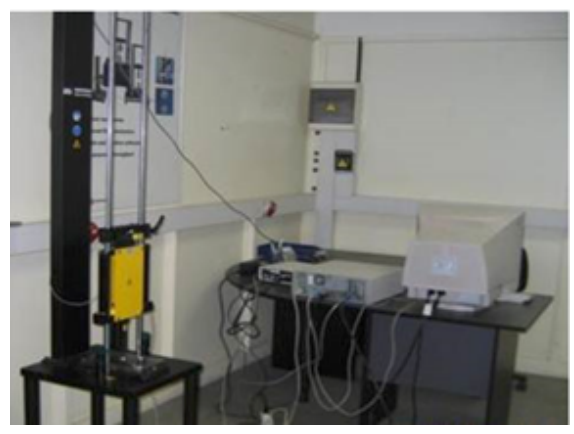

Fig. 1. The Dynatup Model 8200 Impact Test

\footnotetext{
* email: constantin.opranltpc.pub.ro
} 
The specimen's measure is $150 \times 100 \times 15 \mathrm{~mm}$. Data collected by the impulse system was organized, analysed and displayed both graphically and numerically based on PC software. Analysis options include automatic yield and failure point calculations, as well as digital filtering to screen out load cell resonances and noise. Test data could be exported to spreadsheets and charts, as shown in figure 2 for the bio-composites fibre reinforced wooden beech and in figure 3 for the polymeric bio-composites fibre reinforced wooden fir material. In the charts, there are the following graphs: blue line - for variation of energy $E$ in [ $\mathrm{kgm}]$ and the red line - for variation of load F in [kN]. The impulse console is designed to provide intelligent test setup and control with a very flexible interface. This controller displays realtime data while providing access to test set-up controls. Digital display indicates user, exactly what the current settings are, including test drop height, velocity, and impact energy. The used impact mass was $m=3.94 \mathrm{~kg}$.

The significance of the notations are as follows: $\mathrm{H}$ in [mm] - the sample drop height; $v$ - the impact velocity in $[\mathrm{m} / \mathrm{s}] ; \mathrm{E}$ - the total energy in [Kgm]; and $\mathrm{W}$ is the total energy in [J].

\section{Results and discussions}

The used system is a fully-integrated electronics and software package that increases impact testing productivity through automated data acquisition, analysis and reporting. Impulse utilizes an impact force transducer and falling mass velocity detector to capture load vs. time information from instrumented impact tests. Table 1 presents the experimental results collected for 5 samples from polymeric bio-composites fibre reinforced wooden

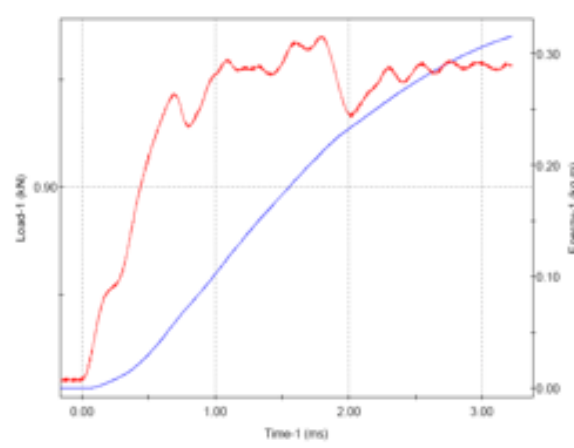

a) Sample $1, \mathrm{H}=50 \mathrm{~mm}$

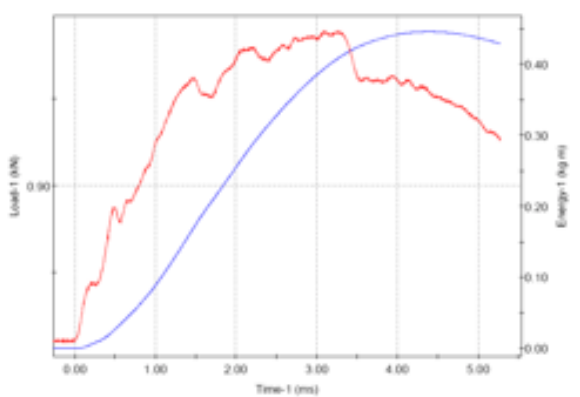

d) Sample 4, H= $80 \mathrm{~mm}$

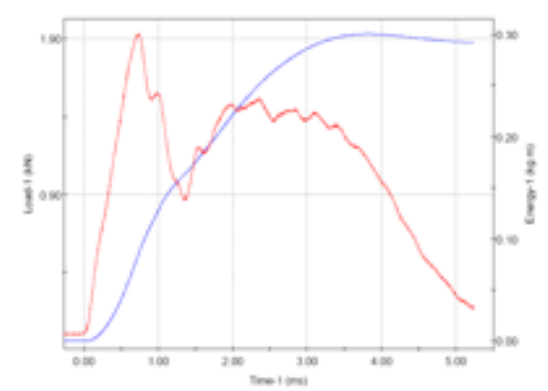

a) Sample $1, \mathrm{H}=50 \mathrm{~mm}$

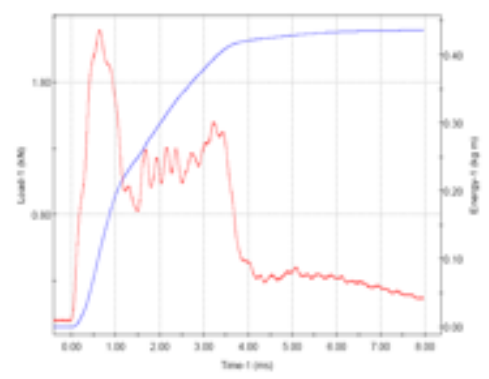

d) Sample 4, H=80 mm

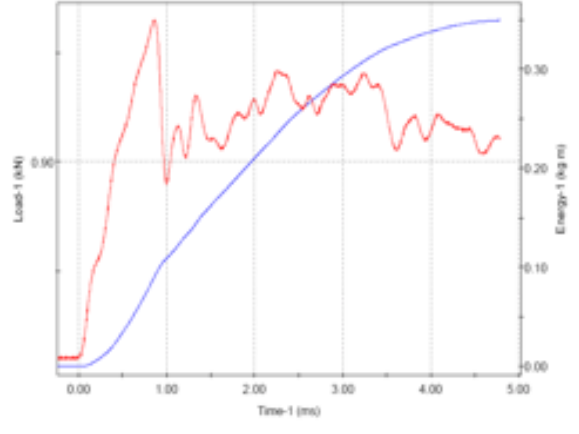

b) Sample $2, \mathrm{H}=60 \mathrm{~mm}$

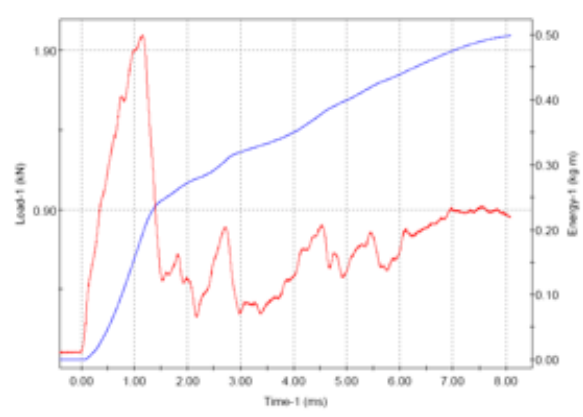

e) Sample 5, H=90mm

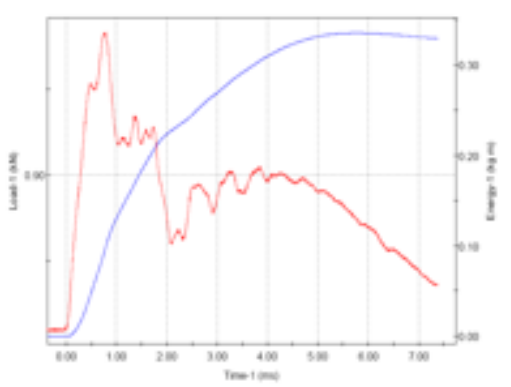

b) Sample $2, \mathrm{H}=60 \mathrm{~mm}$

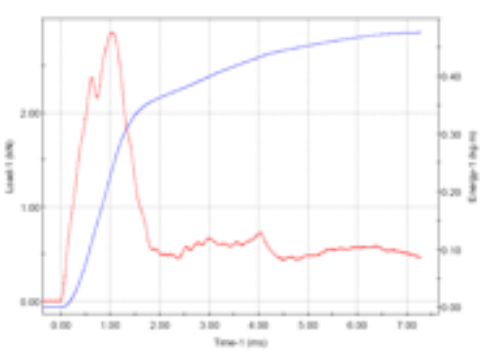

e) Sample 5, H=90 mm

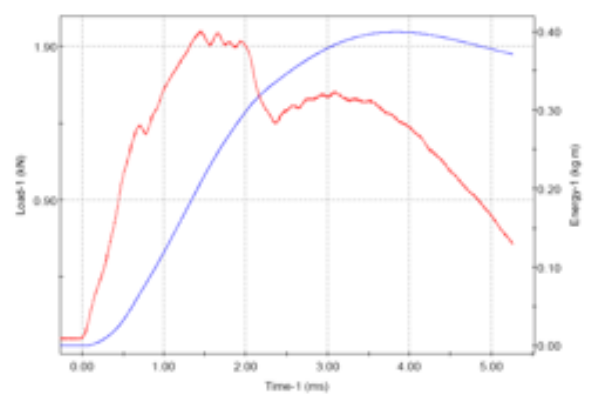

c) Sample $3, \mathrm{H}=70 \mathrm{~mm}$

Fig. 2. Polymeric bio-composites fibre reinforced wooden beech samples' charts 


\begin{tabular}{|c|c|c|c|c|c|c|}
\hline \multirow[t]{2}{*}{ Sample } & \multicolumn{5}{|c|}{ Characteristics } & \multirow{2}{*}{$\begin{array}{c}\text { Results } \\
\text { Type of the impact }\end{array}$} \\
\hline & $\stackrel{\mathrm{m}}{[\mathrm{kg}]}$ & $\begin{array}{c}\mathrm{H} \\
{[\mathrm{mm}]}\end{array}$ & $\begin{array}{c}\mathrm{v} \\
{[\mathrm{m} / \mathrm{s}]}\end{array}$ & $\begin{array}{c}\mathrm{E} \\
{[\mathrm{Kg} \mathrm{m}]}\end{array}$ & $\begin{array}{l}\mathrm{W} \\
{[\mathrm{J}]}\end{array}$ & \\
\hline 1 & \multirow{5}{*}{3.94} & 50 & 1.0452 & 0.3156 & 3.0941 & Without break \\
\hline 2 & & 60 & 1.0962 & 0.3493 & 3.4245 & Without break \\
\hline 3 & & 70 & 1.1963 & 0.3712 & 3.6392 & Without break \\
\hline 4 & & 80 & 1.2720 & 0.4287 & 4.2029 & Without break \\
\hline 5 & & 90 & 1.3731 & 0.4985 & 4.8872 & Without break \\
\hline
\end{tabular}

Table 1

POLYMERIC BIO-

COMPOSITES FIBRE

REINFORCED WOODEN

BEECH-EXPERIMENTAL

RESULTS

\begin{tabular}{|c|c|c|c|c|c|c|}
\hline \multirow[t]{2}{*}{ Sample } & \multicolumn{5}{|c|}{ Characteristics } & \multirow{2}{*}{$\begin{array}{c}\text { Results } \\
\text { Type of the impact }\end{array}$} \\
\hline & $\underset{[\mathrm{kg}]}{\mathrm{m}}$ & $\begin{array}{c}\mathrm{H} \\
{[\mathrm{mm}]}\end{array}$ & $\begin{array}{c}\mathrm{v} \\
{[\mathrm{m} / \mathrm{s}]}\end{array}$ & $\begin{array}{c}\mathrm{E} \\
{[\mathrm{Kg} \mathrm{m}]}\end{array}$ & $\begin{array}{l}W \\
{[\mathrm{~J}]}\end{array}$ & \\
\hline 1 & \multirow{5}{*}{3.94} & 50 & 1.0096 & 0.2920 & 2.8627 & Total break \\
\hline 2 & & 60 & 1.0952 & 0.3298 & 3.2333 & Total break \\
\hline 3 & & 70 & 1.1900 & 0.3371 & 3.3049 & Total break \\
\hline 4 & & 80 & 1.2812 & 0.4360 & 4.2745 & Total break \\
\hline 5 & & 90 & 1.3388 & 0.4758 & 4.6647 & Total break \\
\hline
\end{tabular}

Table 2

POLYMERIC BIO-

COMPOSITES FIBRE

REINFORCED WOODEN

FIR - EXPERIMENTAL RESULTS

Fig. 4. Polymeric bio-composites fibre reinforced wooden beech, left side $(a, b, c, d, e)$ and polymeric bio-composites fibre reinforced wooden fir, right side

$(1,2,3,4,5)$
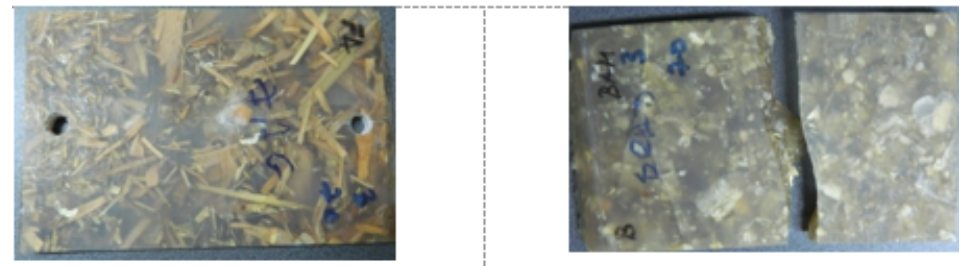

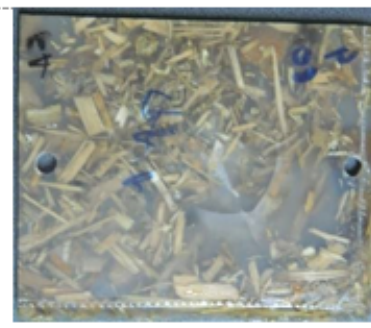

Sample d $H=80 \mathrm{~mm}$, wooden beech Sample $4, H=80 \mathrm{~mm}$, wooden fir
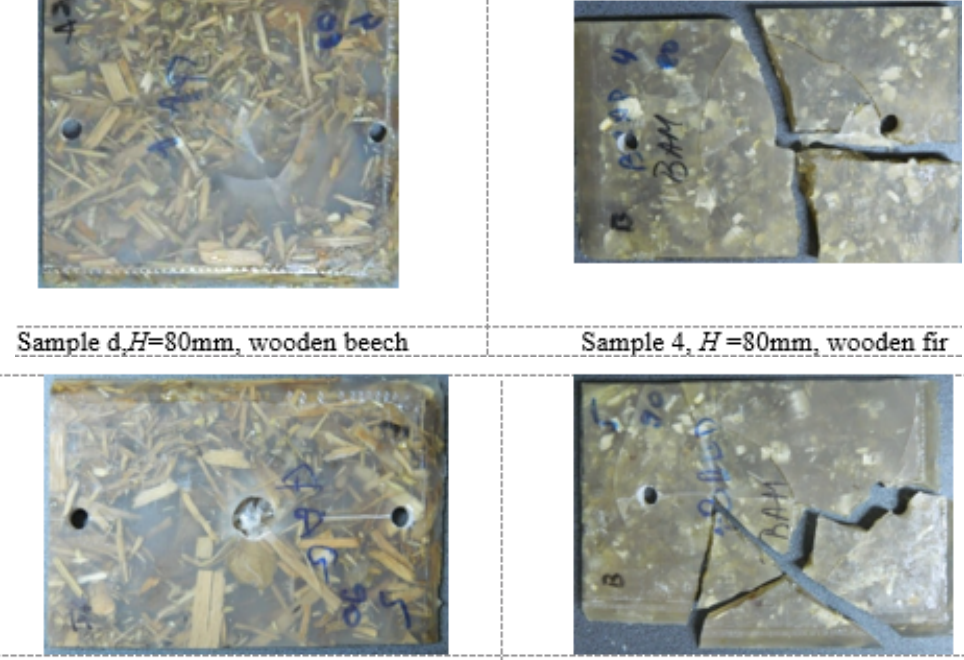

beech and table 2 shows the results for samples made of polymeric bio-composites fibre reinforced wooden fir material.

Figure 4 presents the photographs taken with the polymeric bio-composites fibre reinforced wooden beech, left side $(a, b, c, d, e)$ and polymeric biocomposites fibre reinforced wooden fir, right side (1, $2,3,4,5)$ used to determine the resistance to impact, after performing the impact tests. As it can be observed from the pictures, the materials behave very differently at high rates of loading. 
In figure 5 and in figure 6 the diagrams of height variation on impact speed and energy for polymeric bio-composites fibre reinforced wooden beech are presented, while figure 7 and figure 8 show diagrams height variation on impact speed and energy for polymeric bio-composites fibre reinforced wooden fir.
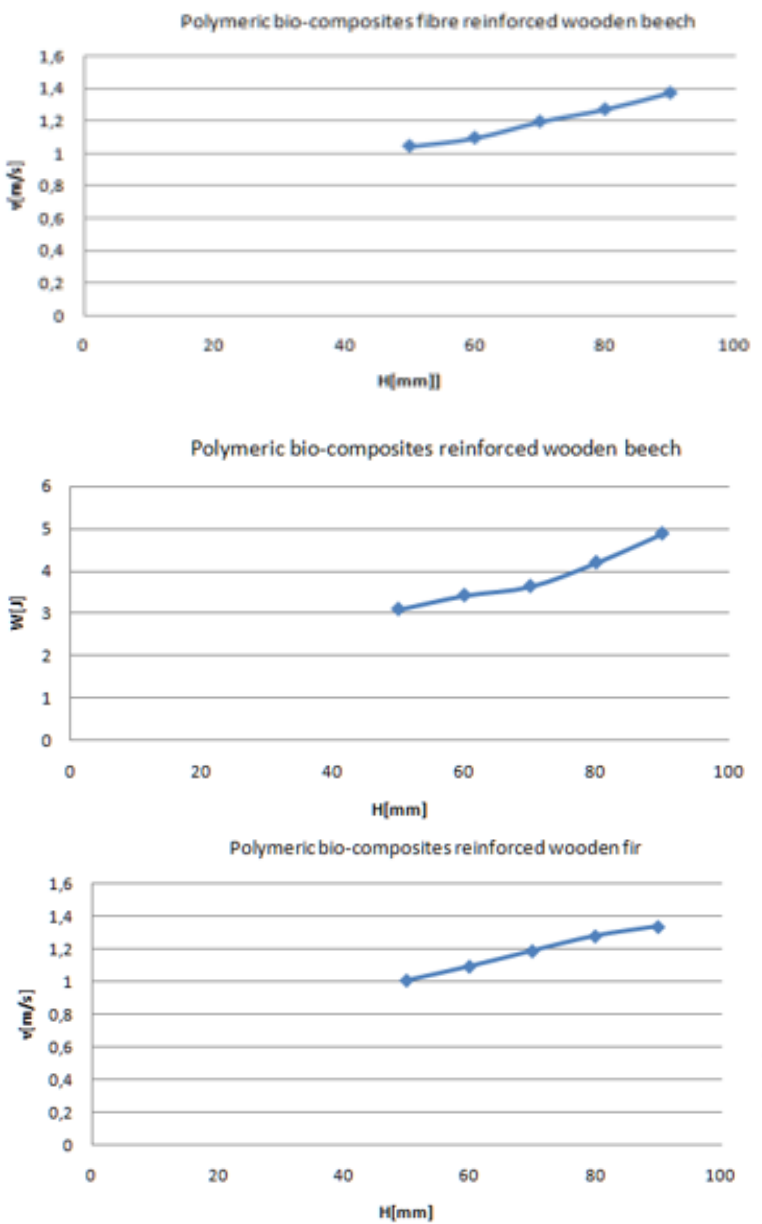

Polymeric bio-composites reinforced wooden fir

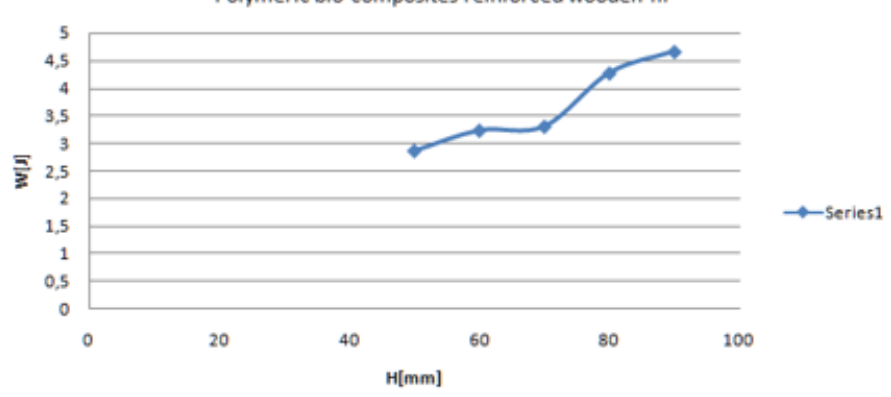

\section{Conclusions}

The polymeric bio-composites fibre reinforced wooden beech and polymeric bio-composites fibre reinforced wooden fir materials behave very differently at different rates of loading and that is why static strength tests cannot be used to predict impact behaviour, taking into account the fact that most orthopaedic prostheses are intended to be used in dynamic conditions.

For polymeric bio-composites fibre reinforced wooden beech specimen, break type evidences low dependence on the drop height, as for h: $50-90 \mathrm{~mm}$ there is no breakage. For polymeric bio-composites fibre reinforced wooden fir specimen, we observed that for the same drop height, $h=$ 50-90 mm relevant failure occurs.

Polymeric bio-composites fibre reinforced wooden beech material proves good elasticity, when compared to polymeric bio-composites fibre reinforced wooden fir material.

Standard impact test method represents an important tool for raw material research and quality control. When the total energy, W [J] accumulates in time and, then

Fig. 5. Chart speed depending on the height of impact for polymeric bio-composites fibre reinforced wooden beech

Fig. 6. Chart total energy depending on the height of impact for polymeric bio-composites fibre reinforced wooden beech

Fig. 7. Chart of speed depending on the height of impact for polymeric bio-composites fibre reinforced wooden fir

Fig. 8. Chart of total energy depending on the height of impact for polymeric bio-composites fibre reinforced wooden fir

increases, it achieves a level of constancy, which proves that it is absorbed by the bio-composite polymeric material.

Given the diversity of application areas for bio-composite polymers and especially in the medical field, the possibility of developing new models of equipment and instruments used in medical rehabilitation that meet both conditions: nontoxic properties and biodegradable materials, where further medical studies must certify increased compliance between polymers and patient skin [15] and resistance to impact and external forces but also allows customizing the devices used, we believe there are vast research directions from a multidisciplinary perspective to include engineers and material specialists, doctors, design engineer and specialists in the biomechanics field.

In future studies in this area, researchers should track and correlate the action of bio-composite products used for medical purposes. Devices that come into contact with 
patients' skin may cause interactions with disinfectants used for hand disinfection [16].

\section{References}

1. MOHAMMED, L., ANSARI, M.N.M., PUA, G., JAWAID, M., ISLAM, S., A Review on Natural Fiber Reinforced Polymer Composite and Its Applications. International J ournal of Polymer Science. 2015.

2. QUARSHIE, R., CARRUTHERS, J., Technology Composites Overview, Available from: http://netcomposites.com/guide-tools/tools/ biocomposites-guide/, accessed on 20.10.2016

3. BEG, M.D.H., PICKERING, K.L., Mechanical performance of Kraft ûbre reinforced polypropylene composites: Inûuence of ûbre length, ûbre beating and hydrothermal ageing. Composites: Part A. 2008; p. 1748-1755.

4. CHEUNG, H-Y., HO, M-P., LAU, K-T., CARDONA, F., HUI, D., Natural ûbre-reinforced composites for bioengineering and environmental engineering applications. Composites: Part B. 2009; p. 655-663.

5. EDUCATION ACfGM. Accreditation Council for Graduate Medical Education. [Online].; 2016. Available from: http://www.acgme.org/ Specialties/Overview/pfcatid/17.

6.GRISSON, S.P., BLANTON, S., Treatment of upper motoneuron plantar flexion contractures by using an adjustable ankle-foot orthosis. Archives of Physical Medicine and Rehabilitation. 2001; p. 270-273. 7. TANG, P.C., RAVJI, K., KEY, J. J., MAHLER, D.B., BLUME, P.A., SUMPIO, B., Let Them Walk! Current Prosthesis Options for Leg and Foot Amputees. J ournal of the American College of Surgeons. 2008: p. 548560.

8. POMERANZ, B., ADLER, U., SHENOY, N., MACALUSO, C., PARIKH, S., Prosthetics and Orthotics for the Older Adult with a Physical Disability. Clinics in Geriatric Medicine. 2006: p. 377-394.
9. ROGOZEA L., LEASU F., REPANOVICI A., BARITZ M., Ethics, robotics and medicine development, Proceedings of the 9th WSEAS International Conference on Signal Processing, Robotics and Automation, 2010, p.264

10. HIEU, L.C., ZLATOV, N., VANDER, S.J., BOHEZ, E., BINH, P.H., KHANH, L., ORIS, P., TOSHEV, Y., Medical rapid prototyping applications and methods. Emerald Insight. 2005, p.284-292.

11. COTOROS, D., BARITZ, M., OPRAN, C., BACANU GH., Aspects Concerning Impact Tests on Composites for Rigid Implants, World Congress on Engineering, Imperial College London, 2009, pp.1658 12. OPRAN, C., BLAJINA, O.\& MARINESCU, A. Researches concerning the behavior at impact of the polymeric composite structures type omega. In Proceedings of Advanced composite materials engineering and advanced in human body protection to vibrations; 2008, p. 272.

13. C. OPRAN, A. MARINESCU, A. \& BLAJINA, O. Researches concerning the behavior at impact of the polymeric composite sandwich structures type plaque. In Proceedings of Advanced composite materials engineering and advanced in human body protection to vibrations; 2007, p. 266.

14. *** http://www.instron.com - Dynatup Drop Weight Impact Test Machine, Impact Testing Solutions Brochure, pod_8200_rev5_0606, 2006.

15. SCUTARIU, M.M., MATEI, M.N., MACOVEI, G., SURDU, A., A Clinicalstatistical Study of Oral Mucosa Pathology Induced by the Acrylic Resins from Removable Dentures in Older Patients, Mat. Plast., 52, no, 3, 2015, p. 402

16. BARLEAN, L. , TATARCIUC, M., BALCOS, C., VITELARIU, A.M., MOISEI, M., CHISCOP, I., SCUTARIU, M.M., Dentists Occupational Exposures To Chemicals During Hands Hygiene In The Dental Offices In lasi, Rev. Chim. (Bucharest), 66, no.10, 2015, p. 1696

Manuscript received: 12.02 .2017 